\title{
Learning Styles of Saudi ESP Students
}

\author{
Saleem Mohd Nasim ${ }^{1}$ \& Syeda Mujeeba ${ }^{2}$ \\ 1,2 English Language Unit, Preparatory Year Deanship (PYD), Prince Sattam bin Abdul Aziz \\ University, Saudi Arabia. \\ 1Email: s.nasim@psau.edu.sa, educationalresearch80@gmail.com. \\ https://orcid.org/0000-0001-5110-1547 \\ 2Email: m.syeda@psau.edu.sa, syedaroma2002@gmail.com
}

\begin{abstract}
Explorations in learning styles have proved the significance of the ways students approach, assimilate, and process information. Students' perceptions and their organization influence the quality of language learning and guide them towards autonomy too. This study attempts to identify the preferred perceptual learning styles of 86 Saudi English for Specific Purposes (ESP) female students in the Preparatory Year Deanship at Prince Sattam bin Abdul Aziz University, Saudi Arabia. To accomplish this aim, a Perceptual Learning Style Preference Questionnaire (PLSPQ) developed by Joy Reid (1987) was used. The results showed that the participants' major learning styles were Kinesthetic, Group, Auditory, Visual, and Tactile, whereas their minor style was Individual. The analysis of the data also revealed that the most preferred learning style was the Kinesthetic learning style $(18.64 \%, \mathrm{M}=4.42)$, and the least preferred one was the Individual learning style (14.30\%, $M=3.39$ ). The second to fifth places belonged to Group (17.19\%, $M=4.07$ ), Auditory (16.81\%, $\mathrm{M}=3.98)$, Visual $(16.55 \%, \mathrm{M}=3.92)$, and Tactile $(16.52 \%, \mathrm{M}=3.91)$ learning styles. The findings have implications for teachers, syllabus designers, and researchers to take into consideration students' preferred learning styles for language learning while teaching, changes in the learning environment, and material adaptation.
\end{abstract}

Keywords: learning styles, individual differences, Saudi ESP students, PLSPQ, PYP

\section{Introduction}

The idea that each person is different is not new. It was thought long ago by Aristotle, who believed that every child had individual talents and specific skills (in Reiff, 1992, p.7). Even two identical twins can be distinguished on the basis of the approaches they use to master the same skill or subject matter. The quality of being unique can be with regard to 'a single characteristic or a number of behavioral patterns in varying degrees' (Good as cited in Mangal, 2012, P. 119). Human beings may differ from one another in receiving, processing, and absorbing inputs and then operating or monitoring both internal and external stimuli according to their peculiar preferences. These preferences, 'as individual as a signature' (Dunn et al., 1989), are called learning styles and 'distinguish people in their totality' (Good as cited in Mangal, 2012, P. 119). Research in intelligence and personality has substantiated this notion of diversity among individuals and ascribed it to a number of variables, such as 'emotional, cognitive, and sensory influences' (Willing,

This Open Access article is published under a Creative Commons Attribution Non-Commercial 4.0 International License (http://creativecommons.org/licenses/by-nc/4.0/), which permits non-commercial re-use, distribution, and reproduction in any medium, provided the original work is properly cited. For citation use the DOI. For commercial re-use, please contact editor@rupkatha.com. 
1988), environmental, sociological, and physical elements (Dunn \& Dunn, 1978, 1979), 'experiences of the past, needs of the present situation, and inherited traits' (Kolb, 1984).

In an academic setting, learning styles refer to how learners choose to learn rather than what they learn. Their manners of learning are not the same, but different in a variety of ways, which affect the quality of their learning and ultimately influence the outcomes of their learning (Oxford \& Ehrman, 1988; Ehrman \& Oxford, 1989, 1990). Successful completion of learning tasks also depends on learning styles (Richards \& Schmidt, 2014). On the contrary, 'frustration and failures in learning can be the result of a mismatch between teaching and learning' (Peacock, 2001). Therefore, identifying the favorite learning styles of students and organizing their learning experiences according to those styles has become imperative. If students' learning style preferences are congruous with their learning experiences and tasks, they will develop a better understanding of their subjects and their individual needs can be fulfilled in the areas they require additional support.

The significance of learning styles in language learning is mentioned by many researchers. Oxford (1989) stated that strategies and styles of language learning are the most important elements that have a major impact on learners' performance. Language learning activities require a variety of learning styles and strategies to be completed successfully. Krashen (1982) acknowledged that language learning is influenced by the choice of learning styles learners make. Similarly, Skehan (as cited in Kirkpatrick, 2011) also enumerated many implications of learning styles in SLA. The relevance of learners' perceptual learning styles in terms of ESP has also been highlighted. Widdowson (1983) suggested incorporating the process through which learners acquire their learning styles and strategies into the ESP courses and the teaching methodology to produce the desired outcomes. ESP lessons are planned to meet the requirements and objectives of the students. As they have diverse personalities, they have specific ways of learning, which might affect their language learning performance significantly. The appropriateness of learning materials, when tailored to language learning styles, facilitates the language learning process. In this regard, Dunn and Dunn (1978) stated, "If a student does not learn the way we teach him, we must teach him the way he learns" (Dunn and Dunn, 1978; cited in Hood, n.d., para. 29). Therefore, this study aims at exploring the ways students learn, i.e., learning styles, of ESP learners so that their academic performance can be improved and teachers can adjust their styles according to their needs.

\section{Theoretical Framework of the Study}

\section{Concept and Models of Learning Styles}

The concept of 'learning style' is multidimensional and has no one-agreed-upon definition. It has more commonly been defined in phenomenological terms as 'a set of behaviors that enable someone to adjust to a particular environment' (Gregorc, 1979). Keefe (1979) included physiological, affective, and cognitive variables, which are relatively constant indicators of the ways students perceive, interact with, and react to the environment of learning. Reid (1987) focuses on individual differences and describes the term as "the variations among learners in using

one or more senses to understand, organize, and retain experience" (Reid, 1987, P.89). This variance in the concept has led Dunn \& Dunn $(1978,1979)$ to itemize as many as 18 elements to define it, which they organized under five categories. In a similar vein, Oxford (2003) popularly 
defined learning styles as general approaches such as visual, auditory, analytic, global, etc., employed by learners in the process of learning a new language or in mastering some other study material (Oxford, 2003, p.2). In spite of lacking unanimity in defining the concept, the significance of learning styles has been widely acknowledged in many areas, including teaching and learning.

The prismatic nature reflected in the definitions of the construct prompted psychologists to develop as many as 'seventy models of learning styles with a minimum of two variables in each model' (Xu, 2011). These models can be categorized as (a) perceptual learning style models based on sensory perceptions, viz. auditory (learning by listening), practical/kinesthetic (learning by doing), visual (learning by seeing), writing or reading (learning by processing words), and tactile learning (learning by using hands), (b) cognitive learning style models based on the involvement of cognitive processes and describing learners as field-independent (analytic) or field dependent (global), holists or serialists, convergent or divergent thinkers, and scanners or focusers; and (c) personality learning style models based on the types of personality. These models categorize learners as reflective and impulsive.

These models, while widely accepted and supported by numerous research tools, cannot provide a complete picture of the learners' experiences. One potent reason is that most of them reflect a multitude of features and have composite characteristics. Their learning-style patterns are not dichotomous. Labeling them with a particular type of learning style might be inappropriate. However, it cannot be denied that a learner may strongly manifest a particular type of learning style when measured on a particular model and marked out accordingly. In this study, the researchers will use Reid's model of Perceptual Learning styles to find out the ESP learners' styles.

\section{Previous Researches}

Analyzing learning styles has become a major concern in many fields of education over the past fifteen years (Corbett \& Smith, 1984), and research has been conducted on identifying native and non-native learners' learning styles around the world. They have proved the correlation of learning styles with personality, heredity, age, gender, objectives of learning, instructors' expectations, socio-cultural environment, linguistic selection, and past occurrences. A positive relationship between learning styles and methodology on learners' academic progress has also been investigated, which revealed that students' achievement increased when teaching methods, materials, and the learning environment matched their learning styles. Scholars have used a variety of models to measure them. However, a review of some studies using only PLSPSQ will be presented here as it is being used in this study.

Melton (1990) investigated the learning styles of 331 participants in five Chinese institutes. The study revealed that students had more than one learning style, viz., Kinesthetic, Tactile, and Individual. This study also showed that if students were aware of their personal learning style, then they could find effective ways to become better learners. Furthermore, a conscious knowledge of their learning styles would positively assist the instructor in planning and organizing their learning experiences.

With the help of PLSPQ, Mulalic et al. (2009) determined the perceptual learning style preferences of 160 (74 female and 86 male) ESL students at UNITEN, Malaysia in terms of gender 
and race. The respondents were selected through stratified random sampling techniques. There were 56 Malays, 52 Chinese and 52 Indian students. The findings revealed that Kinesthetic was the dominant, but Auditory, Group, and Visual learning styles were minor. Individual and Tactile learning styles were shown to be negatively preferred.

Alkhatnai (2011) employed a mixed-method design to assess the preference for learning styles among 100 Saudi female and male first-year EFL undergraduates whose major was English with a writing course (Writing III) in both online and traditional classrooms at King Saud University, Saudi Arabia. On Reid's PLSPQ, Saudi male and female participants indicated their least favorite learning style as Individual (9\%) and the most preferred one as Tactile learning style (25\%). Other favorite learning styles, i.e. Auditory (19\%), Visual (18\%), Group (15\%), and Kinesthetic (14\%) were ranked second to fifth.

In another study carried out by Naserieh and Anani Sarab (2013) at Shahid Beheshti University, Iran, the effect of gender, proficiency level, discipline, and age among 138 graduates was determined. A slightly modified version of PLSPQ elicited participants' main preference towards Tactile and Kinesthetic learning styles, but no liking for Group learning style. Their subjects, age, gender, and proficiency level were also shown to have influenced their choices of styles.

Chen and Hung (2015) identified ESP students' learning style preferences in Taiwan at university level using Reid's PLSPQ. They stratified the sample of 1,105 undergraduates from 10 schools studying ESP. The findings indicated that Taiwanese university ESP students selected Kinesthetic and Auditory learning styles, confirming the results of Reid's (1987) study.

In a recent study conducted on 120 Saudi EFL learners, Khalil and Sabir (2019) investigated whether their learning styles were influenced by their majors, viz., Law, Architecture, Education, and Speech and Hearing. The subjects with Law, Architecture, and Speech and Hearing as their majors informed Kinesthetic learning style as the most commonly used. Participants with Education major preferred Auditory as their favorite learning style.

\section{Current Research}

A plethora of research on the topic of learning style preferences has been conducted in EFL and ESL contexts, but recognizing perceptual learning style preferences of ESP learners has received less attention, and 'a few studies have focused on this field' (Alsamadani, 2013). As ESL/EFL is different from ESP (Chen and Hung, 2015) and EFL/ESL, learners, with their goals, interests, and individual differences, make a transition when they start studying ESP. Being cognizant of these learners' styles of learning during the teaching-learning process will be fruitful. This highlights the significance, as well as the necessity of identifying students' perceptual styles of learning in the context of ESP. Therefore, this study is aimed at identifying the learning styles and preferences of Saudi female ESP learners. This study seeks to answer the following research questions:

1. What are the learning style preferences of Saudi ESP students at PYD, Prince Sattam bin Abdulaziz University?

2. Which learning style is most preferred by Saudi ESP students?

3. Which is the least preferred learning style among Saudi ESP students? 
5 | Learning Styles of Saudi ESP Students

4. What is the percentage of learning styles preferred by Saudi ESP students?

5. What is the classification of Saudi ESP learners' preferences under minor, major, and negligible learning styles?

\section{Methodology}

\section{Sample}

The participants were 86 Saudi female students between the ages of 17-23 years studying EMP (English for Medical Purposes) in the Deanship of Preparatory Year at Prince Sattam bin AbdulAziz University, Saudi Arabia. All of them were native speakers of Arabic, selected through a convenience sampling method in the second semester of the 2019-2020 session. All students had a minimum of six years of exposure to English before entering the university. They were required to study 'Career Paths' by Virginia Evans, Jenny Dooley, and Trang M. Tran (2012) for 9 hours per week for 15 weeks. They had already studied Q: Skills for Success, Special Edition, Level 2 Reading and Writing Book in the first semester. They consented to participate in this survey and were given information about the purpose of the study and its methodology. They were also informed that the findings of this survey would neither be made public nor would they influence their course grades.

\section{Instrument}

A number of instruments to identify learning styles have been developed by scholars for both non-native and native speakers of English. Some popular learning-style scales for native speakers of English were constructed by Kolb (1976, 1984), Dunn, Dunn, \& Price $(1975,1979)$, and Riechmann \& Grasha (1974). The scales meant for speakers other than English were the Style Analysis Survey by Oxford (1993), the Learning Channel Preference Checklist by O'Brien (1990), and the Perceptual Learning Style Preference Questionnaire (PLSPQ) by Reid (1984).

For this study, Joy Reid's (PLSPQ) was preferred because it has been piloted and standardized on both non-native and native speakers (Reid, 1987). Another reason is that it has high reliability and validity. On her scale, there are 30 randomly ordered statements, which are further categorized into six groups (five statements in each category), i.e., Tactile, Auditory, Visual, Individual, Kinesthetic, and Group. The respondents were required to choose 5 if they strongly agree, 4 if they agree, 3 if they can't decide, 2 if they disagree, or 1 if they strongly disagree with any statement on the questionnaire. The reliability of the questionnaire and its sub-parts measured in Cronbach's Alpha is presented in table 1:

Table 1: Learning Style Sub-scales with their items and reliability coefficient

\begin{tabular}{|c|c|c|}
\hline Learning Style Sub-scales & Items & Cronbach's alpha \\
\hline 1. Visual & $6,10,12,24$, and 29 & .69 \\
\hline 2. Tactile & $11,14,16,22$, and 25 & .72 \\
\hline 3. Auditory & $1,7,9,17$, and 20 & .74 \\
\hline 4. Group & $3,4,5,21$, and 23 & .72 \\
\hline 5. Kinesthetic & $2,8,15,19$, and 26 & .71 \\
\hline 6. Individual & $13,18,27,28$, and 30 & .85 \\
\hline Overall & all 30 items & .84 \\
\hline
\end{tabular}




\section{Procedure}

PLSPQ was slightly modified, translated into Arabic and reviewed by three bilingual experts. It was then deployed through Google Forms and sent to the participants through WhatsApp with the help of their teachers during the second semester of the year 1441-1442, corresponding to the session 2019-2020. To analyze the results, the study adopted the descriptive statistics research method. The collected data was coded and the frequency, percentage, means, and SDs of all 30 items were calculated with the help of SPSS-25. For calculating the means and SDs according to the particular learning style sub-scale, the means and SDs of 30 items were divided into six groups of perceptual learning styles (as they are categorized in the PLSPQ). For the sake of interpretation, participants' preferences $1=$ strongly disagree and $2=$ disagree were combined into one group as negative preferences, while $4=$ agree and $5=$ strongly agree were classified as positive preferences. Undecided was represented by 3 . The means and SDs of five sub-sets were also interpreted.

Further, the overall conversion score of the entire PLSPQ is divided into three groups: (024) negligible, (25-37) minor, and (38-50) major learning styles. Minor preferences relate to learning methods that learners can do effectively to meet the requirements of the tasks, whereas major preferences refer to learning methods that students find natural and normal. Negligible preferences refer to any learning approach that students struggle to study with, and as a result, they will not pick it on their own (Psaltou-Joycey \& Kantaridou, 2011).

\section{Results}

To analyze the data in detail and answer the first question, all six sub-sets with their items are presented below:

Table 2: Kinesthetic Learning Style

\begin{tabular}{|l|c|c|c|c|c|c|c|}
\hline \multicolumn{1}{|c|}{$\mathrm{K}$} & SA\% & A\% & U\% & D\% & SD\% & Mean & SD \\
\hline S2-I prefer to learn by doing something in class. & 67 & 21 & 2 & 9 & 0 & 4.47 & 0.93 \\
\hline S8-When I do things in class, I learn better. & 62 & 38 & 0 & 0 & 0 & 4.62 & 0.49 \\
\hline S15-I enjoy learning in class by doing experiments. & 65 & 23 & 12 & 0 & 0 & 4.53 & 0.70 \\
\hline $\begin{array}{l}\text { S19-I understand things better in class when I } \\
\text { participate in role-playing. }\end{array}$ & 49 & 40 & 12 & 0 & 0 & 4.37 & 0.69 \\
\hline $\begin{array}{l}\text { S26-I learn best in class when I can participate in } \\
\text { related activities. }\end{array}$ & 40 & 38 & 14 & 8 & 0 & 4.09 & 0.93 \\
\hline Overall & 57 & 32 & 8 & 3 & 0 & 4.42 & 0.75 \\
\hline
\end{tabular}

Table 2 shows the statements of the Kinesthetic learning style with the highest score for statement 8 , with a mean value of 4.62 and a standard deviation of 0.49 and $100 \%$ of the students' preferences, while statement 26 , with a mean value of 4.09 and a standard deviation of 0.93 , has the least score with $78 \%$ of the students' preferences. The table also demonstrates that $88 \%$ of students preferred statements 2 and 15 with mean values of 4.47 and 4.53 and standard deviations 
7 | Learning Styles of Saudi ESP Students

of 0.93 and 0.70 , respectively. Eighty-nine percent of students strongly agreed and agreed with statement 19 , with a mean value of 4.37 and a standard deviation of 0.69 .

Table 3: Group Learning Style

\begin{tabular}{|l|c|c|c|c|c|c|c|}
\hline \multicolumn{1}{|c|}{ G } & SA\% & A\% & U\% & D\% & SD\% & Mean & SD \\
\hline S3-I get more work done when I work with others. & 44 & 30 & 10 & 10 & 5 & 3.99 & 1.18 \\
\hline S4-I learn more when I study with a group. & 52 & 28 & 10 & 9 & 0 & 4.23 & 0.98 \\
\hline S5-In class, I learn best when I work with others. & 49 & 30 & 12 & 9 & 0 & 4.19 & 0.98 \\
\hline $\begin{array}{l}\text { S21-I enjoy working on an assignment with two or three } \\
\text { classmates. }\end{array}$ & 38 & 38 & 9 & 9 & 5 & 3.97 & 1.13 \\
\hline S23-I prefer to study with others. & 33 & 48 & 10 & 5 & 5 & 3.99 & 1.02 \\
\hline Overall & 43 & 35 & 10 & 9 & 3 & 4.07 & 1.06 \\
\hline
\end{tabular}

Table 3 shows the preferences for the sub-set of Group learning style. The highest score was recorded for statement 4 , with a mean value of 4.23 , a standard deviation of 0.98 , and $80 \%$ of the students' preferences. On the other hand, statement 21 , with a mean value of 3.97 and a standard deviation of 1.13 , has the lowest score, with $76 \%$ of students' preferences. This also demonstrates that the mean value of statements 3 and 23 is 3.99, with a standard deviation of 1.18 and 1.02 , respectively, with $74 \%$ and $81 \%$ of students' preferences. Seventy-nine percent of students strongly agreed and agreed with statement 5, with a mean value of 4.19 and a standard deviation of 0.98 .

Table 4: Auditory Learning Style

\begin{tabular}{|l|c|c|c|c|c|c|c|}
\hline A & SA\% & A\% & U\% & D\% & SD\% & Mean & SD \\
\hline $\begin{array}{l}\text { S1-When the teacher tells me the instructions, I } \\
\text { understand better. }\end{array}$ & 49 & 43 & 3 & 0 & 5 & 4.31 & 0.92 \\
\hline $\begin{array}{l}\text { S7-When someone tells me how to do something in } \\
\text { class, I learn it better. }\end{array}$ & 43 & 45 & 12 & 0 & 0 & 4.31 & 0.67 \\
\hline $\begin{array}{l}\text { S9-I remember things I have heard in class better than } \\
\text { things I have read. }\end{array}$ & 38 & 26 & 15 & 12 & 9 & 3.72 & 1.33 \\
\hline $\begin{array}{l}\text { S17-I learn better in class when the teacher gives a } \\
\text { lecture. }\end{array}$ & 15 & 38 & 30 & 12 & 5 & 3.48 & 1.04 \\
\hline S20-I learn better in class when I listen to someone. & 36 & 47 & 13 & 0 & 5 & 4.09 & 0.95 \\
\hline Overall & 36 & 40 & 15 & 5 & 3 & 3.98 & 0.98 \\
\hline
\end{tabular}

The statements under the Auditory learning style are presented in table 4 . In this set of styles, statements 1 and 7 have dominant values with their mean scores of 4.31 and $92 \%$ and $88 \%$ of students' preferences, but different standard deviations of 0.92 for statement 1 and 0.67 for statement 7 . The lowest value was recorded for statement 17 , with a mean value of 3.48 and a standard deviation of 1.04 , with $53 \%$ of students' preferences. Almost one-third of participants chose not to disclose their opinions regarding this statement. The mean values of statements 9 
and 20 are 3.72 and 4.09 , with SDs of 1.33 and 0.95 . The percentages of preference for these statements are $64 \%$ and $83 \%$, respectively.

Table 5: Visual Learning Style

\begin{tabular}{|l|c|c|c|c|c|c|c|}
\hline \multicolumn{1}{|c|}{$\mathrm{V}$} & $\mathrm{SA} \%$ & $\mathrm{~A} \%$ & $\mathrm{U} \%$ & $\mathrm{D} \%$ & $\mathrm{SD} \%$ & Mean & SD \\
\hline $\begin{array}{l}\text { S6-I learn better by reading what the teacher writes on } \\
\text { the chalkboard. }\end{array}$ & 44 & 37 & 14 & 5 & 0 & 4.21 & 0.86 \\
\hline S10-When I read instructions, I remember them better. & 30 & 41 & 22 & 7 & 0 & 3.94 & 0.90 \\
\hline S12-I understand better when I read instructions. & 36 & 52 & 9 & 2 & 0 & 4.22 & 0.71 \\
\hline $\begin{array}{l}\text { S24-I learn better by reading than by listening to } \\
\text { someone. }\end{array}$ & 33 & 28 & 21 & 12 & 7 & 3.67 & 1.24 \\
\hline $\begin{array}{l}\text { S29-I learn more by reading textbooks than by listening } \\
\text { to lectures. }\end{array}$ & 29 & 33 & 13 & 16 & 9 & 3.56 & 1.32 \\
\hline \multicolumn{1}{|c|}{ Overall } & 34 & 38 & 16 & 8 & 3 & 3.92 & 1.00 \\
\hline
\end{tabular}

The statements under Visual learning style are presented in table 5 . The dominant statements are 12 (Mean=4.22, SD=0.71) with $88 \%$ of the students' preferences and 6 , with $81 \%$ of the students' preferences and a slight difference in the Mean, 4.21 (SD=0.86). The lowest score $(M=3.56 ; S D=1.32)$ with $52 \%$ preference is for statement 29 . Statements 10 and 24 received $71 \%$ and $61 \%$ of preferences, respectively, with $M=3.94, S D=0.90$ and $M=3.67, S D 1.24$.

Table 6: Tactile Learning Style

\begin{tabular}{|l|c|c|c|c|c|c|c|}
\hline \multicolumn{1}{|c|}{ T } & SA\% & A\% & U\% & D\% & SD\% & Mean & SD \\
\hline S11-I learn more when I can make a model of something. & 43 & 33 & 15 & 9 & 0 & 4.09 & 0.98 \\
\hline $\begin{array}{l}\text { S14-I learn more when I make something for a class } \\
\text { project. }\end{array}$ & 33 & 28 & 27 & 5 & 7 & 3.77 & 1.17 \\
\hline S16-I learn better when I make drawings as I study. & 53 & 16 & 10 & 13 & 7 & 3.97 & 1.34 \\
\hline $\begin{array}{l}\text { S22-When I build something, I remember what I have } \\
\text { learned better. }\end{array}$ & 51 & 30 & 15 & 3 & 0 & 4.29 & 0.85 \\
\hline S25-I enjoy making something for a class project. & 29 & 24 & 21 & 14 & 12 & 3.45 & 1.35 \\
\hline \multicolumn{1}{|c|}{ Overall } & 42 & 26 & 18 & 9 & 5 & 3.91 & 1.14 \\
\hline
\end{tabular}

The penultimate table displays the preferences for the statements under the Tactile learning style. The highest score was recorded for statement 22, with a mean value of 4.29 and a standard deviation of 0.85 . Eighty-one percent of participants chose this. Statement 25 has the least preference (53\%), with the lowest mean value of 3.45 and a standard deviation of 1.35 . The mean values for statements 11 and 16 are 4.09 and 3.97, with standard deviations of 0.98 and 1.34, respectively, with $76 \%$ and $69 \%$ of the students' preferences. Sixty-two percent of participants also strongly agreed and agreed with statement 14, with a mean value of 3.77 and a standard deviation of 1.17 . 
9 | Learning Styles of Saudi ESP Students

Table 7: Individual Learning Style

\begin{tabular}{|l|c|c|c|c|c|c|c|}
\hline \multicolumn{1}{|c|}{ I } & SA\% & A\% & U\% & D\% & SD\% & Mean & SD \\
\hline S13-When I study alone, I remember things better. & 23 & 22 & 31 & 14 & 9 & 3.36 & 1.25 \\
\hline S18-When I work alone, I learn better. & 22 & 27 & 38 & 8 & 5 & 3.53 & 1.07 \\
\hline S27-In class, I work better when I work alone. & 29 & 22 & 27 & 8 & 14 & 3.44 & 1.36 \\
\hline S28-I prefer working on projects by myself. & 14 & 33 & 15 & 14 & 24 & 2.98 & 1.42 \\
\hline S30-I prefer to work by myself. & 33 & 23 & 30 & 2 & 12 & 3.63 & 1.28 \\
\hline \multicolumn{1}{|c|}{ Overall } & 24 & 25 & 28 & 9 & 13 & 3.39 & 1.28 \\
\hline
\end{tabular}

This last table shows the statements in Individual learning style. The highest score is for statement 30 , with a mean value of 3.63 , a standard deviation of 1.28 , and $56 \%$ preferences only. On the other hand, the lowest mean value of 2.98 with a standard deviation of 1.42 is recorded for the statement 28 with $47 \%$ positive preferences. This also means that the mean values of statements 18 and 27 are 3.53 and 3.44 with their standard deviations of 1.07 and 1.36, representing $49 \%$ and $51 \%$ of the students' preferences. Only $45 \%$ of students strongly agreed and agreed with statement 13, with a mean value of 3.36 and a standard deviation of 1.25. Remarkably, many participants could not decide whether they wanted to study alone.

To answer the second and third research questions, i.e., "Which learning style sub-scale of the PLSPQ is most and least preferred by Saudi female ESP students at PYD, Prince Sattam bin Abdulaziz University?" the mean scores and standard deviations of all students' responses, categorized into six sub-sets, are shown in figure 1 :

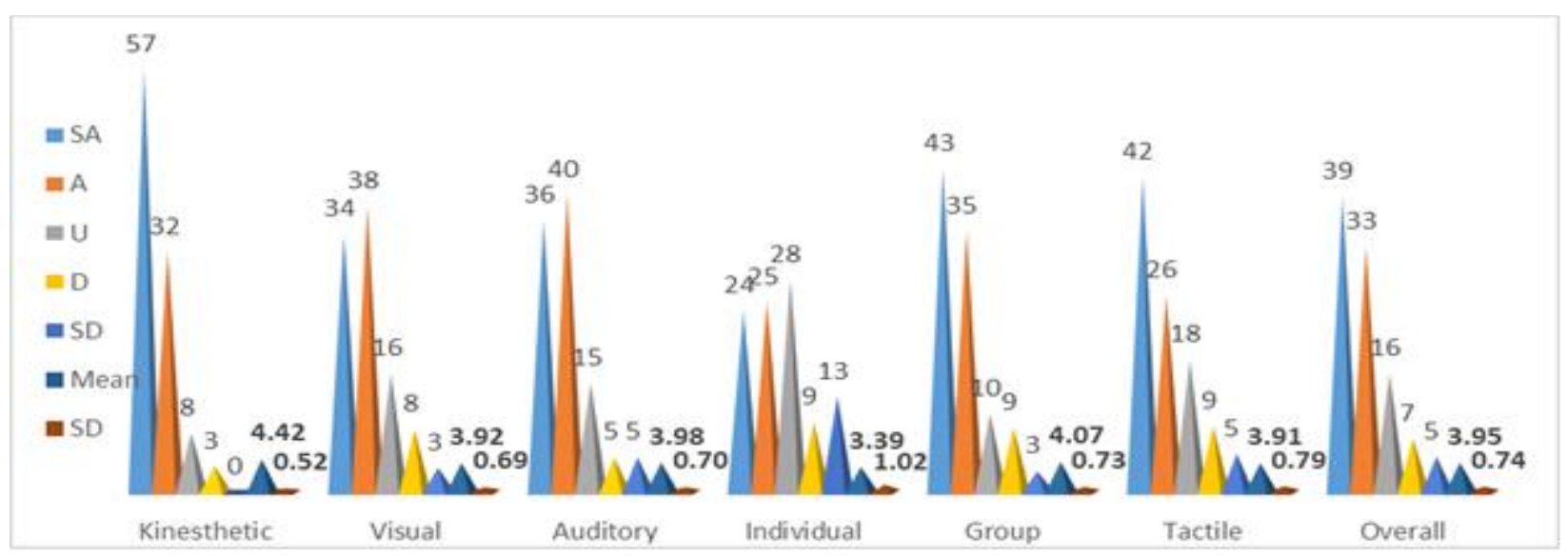

Figure $1 \%$ of Responses of with Means and SDs of Six Learning Styles on PLSPQ (N=86)

The overall mean score of all 30 statements, which constitute six sub-sets of the PLSPQ, is 3.95 ( $S D=0.74$ ). The mean scores of the six categories of learning styles range from 4.42 to 3.39 . Of all the six sub-sets of PLSPQ, the Kinesthetic learning style has the highest mean score of 4.42 ( $S D=0.52$ with $89 \%$ preference). On the other hand, the lowest mean value recorded for Individual learning style is 3.39 ( $S D=1.02$ with $49 \%$ preferences only). The second to fifth places belong to 
Group ( $M=4.07, S D=0.73$ with $78 \%$ preference), Auditory $(M=3.98, S D=0.70$ with $76 \%$ preference), Visual $(M=3.92, S D=0.69$ with $72 \%$ preference), and Tactile $(M=3.91, S D=0.79$ with $68 \%$ preference) learning styles.

To answer the next research question, i.e., the fourth one, a percentage-wise preference for learning styles, is also represented in the chart below:

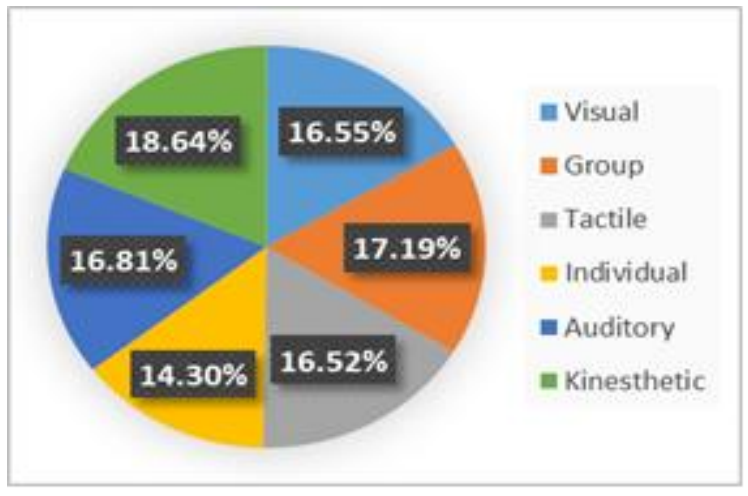

Figure 2: Percentage of Learning Style Preferences

Figure 2 displays the percentage of learning style preferences by the whole population, $\mathrm{N}=86$. This reveals $18.64 \%$ preferences for Kinesthetic, $17.19 \%$ for Group, $16.81 \%$ for Auditory, $16.55 \%$ for Visual, $16.52 \%$ for Tactile, and $14.30 \%$ for Individual learning styles.

To answer the last research question, i.e., the fifth one, the classification of perceptual learning styles is presented in table 2:

Table 8: Classification of Learning Style Sub-scales

\begin{tabular}{|c|c|c|}
\hline Learning Style Sub-scale & Formula $=$ Mean $\times 5 \times 2$ & Results \\
\hline 1. Visual (V) & $3.92 \times 5 \times 2=39.2$ & Major \\
\hline 2. Tactile $(\mathrm{T})$ & $3.91 \times 5 \times 2=39.1$ & major \\
\hline 3. Auditory (A) & $3.98 \times 5 \times 2=39.8$ & major \\
\hline 4. Group & $4.07 \times 5 \times 2=40.7$ & major \\
\hline 5. Kinesthetic $(\mathrm{K})$ & $4.42 \times 5 \times 2=44.2$ & major \\
\hline 6. Individual (I) & $3.39 \times 5 \times 2=33.9$ & minor \\
\hline
\end{tabular}

The findings in table 8 show that Auditory, Tactile, Visual, Group, and Kinesthetic learning style preferences are categorized as major preferences, which is the reason they have a higher percentage of strongly agree and agree than strongly disagree and disagree. On the other hand, Individual learning style is identified as minor because it has a lower percentage of strongly agreeing and agreeing than strongly disagreeing and disagreeing. 


\section{Discussion}

The results of the study reveal that Saudi female ESP learners have a strong pattern for a combination of learning styles. Several studies on learning styles have substantiated that learners use a number of styles while learning English (Melton, 1990; Reid, 1987; Alqahtani, 2011; Zhang et al., 2017; Stebbins, 1993; Alhourani, 2021). This implies that learners cannot be categorized in terms of discrete styles; instead, they employ multiple learning styles in order to facilitate their learning and produce the maximum intended outcome. Using assorted learning styles is also an indication of enhanced classroom performance and better learning outcomes (Reid, 1987).

The choice of not only one but five learning styles as major ones and only one as a minor one was proof that the participants have diverse ways of learning. Furthermore, no style was categorized as negligible. These preferences can be ranked from the first to the sixth as Kinesthetic, Group, Auditory, Visual, Tactile, and Individual. Four out of five statements under the Kinesthetic sub-set were given the highest rank out of 30 statements. Most of them had positive preferences. In contrast, three out of five items under the Individual sub-set were at the bottom, with less than $50 \%$ positive preferences. These choices suggest that students enjoyed experimentation and learned better in the class. Adding to that, fewer participants liked to work alone, even in the class and on projects, too. Only they remembered things better alone.

Naserieh and Anani Sarab (2013) and Yosraveevorakul et al. (2017) found similar results for kinesthetic and individual. This is in contrast with Alkhatnai's (2011) results on Saudi students studying English as a major, who found Tactile as their number one style and Kinesthetic as fifth. However, his participants indexed Individual style, too, as the least beneficial. A more recent observation of Saudi EFL students' learning styles, catalogued by Alhourani (2021), was also different from this study. His students showed a major preference for the Auditory and Group learning styles, but a minor preference for the Kinesthetic, Tactile, and Visual learning styles. They had a negative attitude towards Individual style.

In many other studies, the Kinesthetic learning style was found to be the most popular (Junaid and Ismail, 2018; Chen and Hung, 2015; Khalil and Sabir, 2019; Abu-Asba et al., 2012; Stebbins, 1993). This means that ESP learners, in general, liked to learn through their direct experience and get involved in classroom activities in person. However, in one study on Iranian EFL students, the Kinesthetic style was found to be the least preferred one (Ramezani et al., 2015). Cultural, racial, and linguistic diversity may have been the reason for this difference (Joy \& Kolb, 2009; Reid, 1987).

Tactile was also one of the favorites and major learning styles of the participants. Many previous studies have found similar results among English language learners (Naserieh and Anani Sarab, 2013; Isemonger and Sheppard, 2003; Sun and Teng, 2017).Tactile tops the list when it comes to Iranian EFL learners (Riazi and Mansoorian, 2008). They learn by manipulating and touching things, such as drawing, project completion, model-making, designing, writing, etc. In relation to ESP, it can be safely said that subjects were more interested in hands-on learning opportunities and action-oriented activities, as is the case with medical professionals. Learning experiences could be arranged in accordance with their learning style preferences. 
Visual and Auditory learning styles were identified as major in this study. It goes with Felder's (1996) assertion that students become proficient when they receive verbal and visual input. They are more connected to linguistic competence (Wintergerst et al., 2001). Alqahtani (2011) concluded that Visual is Saudi EFL students' top learning style, whereas Iranian female learners indicated Auditory learning as their major learning style (Ramezani et al., 2015). Peacock (2001) found that Auditory learning is one of the favorite learning styles in the SLA context. Isemonger and Sheppard (2003) also found the same but in an EFL context. Iranian and Thai female EFL students ranked their Auditory learning styles first (Riazi and Mansoorian, 2008; Khamkhien, 2012). Participants showed their interest in oral dictation, discussion with their classmates, and dialogues on tapes or CDs in groups. These findings about Visual and Auditory are contrary to Naseriah and Anani Sarab's (2013) research.

Due to the increasing use of CALL related educational arrangements, students might have preferred more Visual and Auditory learning styles. Nowadays, students can watch educational videos synchronously as well as asynchronously and gain benefits. Regarding ESP, this medium of learning is more beneficial as students may have access to live, online educational opportunities even in remote areas. Apart from this, using audio-visual aids while teaching has always been a favorite means of (language) learning. Starting from pictures, flashcards, drawings, charts, highlighting contrasting information in different colors, diagrams, graphs, audios, videos, and documentaries, all have attracted the attention of (language) learners. Likewise, audio and video files should be made a part of continuous evaluation because this will help them save information for a later time. These realia may also be used as supplementary materials to suit their learning styles.

Individual and Group are widely divergent styles of learning. In this research, Individual learning style was least preferred by Saudi ESP female learners and classified as minor, but Group learning style was the second major and most preferred learning style among them. A larger percentage of research done in this context corroborated the results regarding Individual learning style (Alkhatnai, 2011; Tai, 1999; Naserieh and Anani Sarab, 2013; Yosraveevorakul et al., 2017; Prystiananta, 2018; Peacock, 2001). This research also demonstrated that students of technical subjects did not like working alone (Peacock, 2001). It also meant that ESP participants did not find themselves at ease, thinking better and memorizing information in their studies when they were singled out or away from their mates. ESP is oriented towards teaching technical English, and the books on medical English are more geared towards making them a part of the team. However, there are some exceptions to this, like the findings of Sengsouliya et al. (2019), who found Individual learning style as major.

With regard to Group learning style, many studies (Radwan, 2014; Isemonger and Sheppard, 2003; Yosraveevorakul et al., 2017; Phoenix, 2004; Alireza and Abdullah, 2010) recognized their participants' choice of Group learning style. Surprisingly, Peacock's (2001) and Naserieh's (2009) subjects neither liked Individual nor Group learning styles much. They were not in favor of using these styles while learning English.

Less favoring the Individual style and more favoring the Group indicates that ESP students should be taught English in groups, not in private. They should be given sufficient opportunities for group-work and pair-activities with their classmates. There should be more dialogue-based as 
well as question-answer tasks for them. It has been noticed that in the prescribed book, there are make-believe listening activities in doctor-patient and other medical contexts. Project work is a mandatory prerequisite for the successful completion of these participants' course, which demands engagement in teamwork so that a common goal can be achieved. This might be another reason these participants chose Group learning styles as their favorite and major one.

People, by and large, follow co-operative principles of living, working, and even spending leisure time in Saudi Arabia. They have lived and prayed in groups for many centuries. This instils a sense of 'togetherness' even in students. Therefore, Group learning style was their favorite learning style. Dybvig (2004) cited sociological reasons for females being group learners.

A word of caution is needed here. A low mean on Individual learning style should not be misunderstood as being contrary to autonomous learners. Autonomy focuses more on preparing learners to think critically and making them self-aware; exploiting learning opportunities and employing strategies; and using capabilities to become responsible learners in any situation, whether they work in groups or on peer-to-peer tasks or alone.

\section{Conclusion}

This study, conducted on Saudi female ESP students at PYP, Prince Sattam bin Abdul-Aziz University, using a translated version of Reid's (1987) PLSPQ (from English to Arabic), revealed the Kinesthetic learning style as their most favored (major) and the Individual learning style as the least preferred (minor). Group, Auditory, Visual, and Tactile learning styles were ranked from second to fifth and classified as major. Moreover, the findings have implications for providing a variety of learning activities, considering there are several types of learning styles that can be applied by students. However, to accommodate diverse learning styles, EFL instructors should teach in a balanced manner.

The implications of knowing learning styles are immense in helping educationalists and instructors in syllabus-designing and adapting methodology, particularly for ESP, to address the needs of students (Al Khatib \& Ghosheh, 2013). A positive attitude of students towards learning styles necessitates all stakeholders to acknowledge the significance of their preferences for learning and assist learners in the way they want. To be more precise, incorporating more interactive learning experiences and integrating a multi-sensory approach while working as a team member for collective academic success should be given proper attention. They should be taught using audio-visual aids, incorporating CALL synchronously and asynchronously. Instructors' focus should be more on the practical while they are engaged in the theoretical part of the curriculum. There are activities in the medical profession which can be understood better by doing, i.e., lab work, giving first aid to patients, watching surgical procedures, and doing a dummy practical in the hospital using ESP terminology (jargon and register) in the actual environment would be more fruitful for students than mere lecturing in the classroom. In this way, they will memorize them more easily and faster.

A mismatch between students' styles of learning and their instructors' styles of teaching may cause boredom, lack of interest and attention in class, and a negative backwash on tests. In some cases, all of these lead to a change in the curricula and students dropping out of school (Felder, 1996). Sometimes, a teacher is not cognizant or does not pay attention to the ways his/her 
students prefer to learn the language (Riazi and Riasati, 2007). Therefore, Alzain et al. (2018) proposed an adaptive system of education to accommodate the needs of students, which includes not only tailoring the materials, but also teaching methods, a congenial learning environment, and assessment techniques for learning outcomes. Adaptation does not mean altering the system completely; it refers to 'changing the gears' as per the requirement to produce effectiveness. Such a strategy is a stretch in teachers' styles of teaching, which has been helpful for enhancing learning patterns among students (Christison, 2003).

\section{Limitations of the Study}

The participants for this research were all females and only from one college at Prince Sattam bin Abdul-Aziz University, Saudi Arabia. Hence, a generalization cannot be made for all students as they differ in terms of gender, age, and cultural and linguistic background. The findings are applicable only to the sample in the study. In addition to that, there is a shortage of research on learning styles in Saudi Arabia. Conducting more studies with a larger sample and various variables would produce more reliable and valid results.

Another important point is that the PLSPQ has been under criticism for its low validity and reliability (Itzen, 1995). Therefore, the findings of the perceptual learning style should not be considered definitive. Using a mixed-method technique may provide better results.

\section{Acknowledgement}

This publication was supported by the Deanship of Scientific Research at Prince Sattam Bin Abdulaziz University, KSA.

\section{Declaration of Conflicting Interests}

The researchers declare no conflicting interests.

\section{References}

Abu-Asba, A., Azman, H., \& Mustaffa, R. (2012). Learning styles of Yemeni undergraduate science students. GEMA Online $®$ Journal of Language Studies, 12(2).

Al Khatib, S. A., and Ghosheh, S. K. 2013. Perceptual Learning Style Preferences in Relation to Gender, Academic Achievement and Field of Study among a Sample of UAE College Students. Scholars Journal of Arts, Humanities and Social Sciences, 1(02): 69-80.

Alhourani, A. Q. (2021). Investigating the Match and Mismatch between Students' Learning Styles and Teacher's Teaching Styles in a Saudi School: A Case Study. Journal of World Englishes and Educational Practices, 3(2), 10-20.

Alireza, S. \& Abjullah, M. H. (2010). Language learning strategies and styles among Iranian engineering and political science graduate students studying abroad. Education Research and Reviews 5(2), 35-45.

Alkhatnai, M. (2011). Learning styles of EFL Saudi college-level students in on-line and traditional educational environments. Indiana University of Pennsylvania.

Alqahtani, M. (2011). An investigation into the language needs of Saudi students studying in British postgraduate programs and the cultural differences impacting on them (Doctoral Dissertation). University of Southampton: Southampton, UK. 
Alsamadani, H. (2013). Learning styles among ESP/EFL Saudi students. The International Journal of Learning in Higher Education, 19(2), 1-9.

Alzain, A. M., Clark, S., Jwaid, A., \& Ireson, G. (2018). Adaptive Education based on Learning Styles: Are Learning Style Instruments Precise Enough? International Journal of Emerging Technologies in Learning (JET), 13(9), 41-52. https://doi.org/https://doi.org/10.39 91/ijet.v13i09.8554

Chen, K. T. C., \& Hung, P. (2015). Exploring perceptual learning style preferences of university ESP students in Taiwan. Journal of Teaching English for Specific and Academic Purposes, 3(1), 69-76.

Christison, M.A., 2003. Learning styles and strategies. In: Nunan, D. (Ed.), Practical English Language Teaching. McGraw-Hill, New York, pp.267-288

Corbett, S., \& Wm. Flint Smith. (1984). Identifying Student Learning Styles: Proceed with Caution! The Modern Language Journal, 68(3), 212-221. doi:10.2307/328004

Dunn, R. S., \& Dunn, K. (1979). Learning styles/teaching styles: Should they . . . can they . . be matched? Educational Leadership, 36, 238-244.

Dunn, R., \& Dunn, K. J. (1978). Teaching students through their individual learning styles: A practical approach. Reston, Va: Reston Pub. Co.

Dunn, R., Beaudry, J., \& Klavas, A. (1989). Survey of research on learning styles. Educational Leadership, 46, 50-58.

Dunn, R., Dunn, K., \& Price, G. E. (1975). The learning style inventory. Lawrence, KS: Price Systems.

Dunn, R., Dunn, K., \& Price, G. E. (1979). Identifying individual learning styles. In Student learning styles: Diagnosing and prescribing programs (pp. 39-54). Reston, VA: National Association of Secondary School Principals.

Dybvig, T. (2004). Learning styles. http://www.teresadybvig.com/learnsty.htm

Ehrman, M. E., \& Oxford, R. L. (1990). Adult language learning styles and strategies in an intensive training setting. Modern Language Journal, 54(3), 311-327.

Ehrman, M.E., \& Oxford, R. L. (1989). Effects of sex differences, career choice, and psychological type on adult language learning strategies. Modern Language Journal, 73, 1-13.

Felder, R. M. (1996). Matters of style. ASEE prism, 6(4), 18-23. https://www.engr.ncsu.edu/wpcontent/uploads/drive/11WH3ejjNgI3zYDbIRB6MSGhIQFYkxDIT/1996-LS-Prism.pdf

Gregorc, A.F. (1979). Learning/teaching styles: Potent forces behind them. Educational Leadership, 36, 234236.

Hood, K. (n.d). Exploring Learning Styles and Instruction. (Online) http://jwilson.coe.uga.edu/emt705/ EMT705. Hood.html

Isemonger, I. \& Sheppard, C. (2003). Learning Styles. RELC Journal 34 (2):195-222

Itzen, R. (1995). The dimensionality of learning structures in the Reid Perceptual Learning Style Preference Questionnaire. Unpublished doctoral dissertation, University of Illinois, Chicago.

Joy, S., \& Kolb, D. A. (2009). Are there cultural differences in learning style? International Journal of intercultural relations, 33(1), 69-85.

Junaid, T. M., \& Ismail, N. N. A. (2018). Learning Style Preferences Among Degree Students in Academic English Course in UTHM. International Journal of Engineering \& Technology, 7(3.21), 5256. doi:10.14419/ijet.v7i3.21.17095

Keefe, J. W. (1979). Learning style: An overview. In J. W. Keefe (Ed.), Student learning styles: Diagnosing and prescribing programs (pp. 1-17). Reston, VA: National Association of Secondary School Principals.

Khalil, A., \& Sabir, M. (2019). Saudi EFL Learners' Perceptual Learning-Style Preferences. Education and Linguistics Research, 5(2), 117. https://doi.org/10.5296/elr.v5i2.15711

Khmakhien, A. (2012). Demystifying Thai EFL learners' perceptual learning style preferences. 3L: The Southeast Asian Journal of English Language Studies, 18(1): 61- 74.

Kirkpatrick, R. (2011). Looking at a learning styles research paper: A critical evaluation. Asian EFL Journal, 52, 59-73. Retrieved from www.asian-efl-journal.com/PTA/May-2011-Kirkpatrick.pdf 
Kolb, D. (1976). Learning style inventory. Boston, MA: McBer.

Kolb, D. A. (1984). Experiential learning: Experience as the source of learning and development. Englewood Cliffs, NJ: Prentice Hall.

Krashen. S. (1982). Principles and practice in second language acquisition. Oxford: Pergamon Press.

Mangal, S. K. (2012). Advanced educational psychology. New Delhi, India: PHI Learning.

Melton, C. D. (1990). Bridging the cultural gap: a study of Chinese students' learning style preferences. RELC Journal, 21(1), 29-54.

Mulalic, A., Shah, P. M., \& Ahmad, F. (2009). Perceptual learning styles of ESL students. European journal of social sciences, $7(3), 101-113$.

Naserieh, F. (2009). The Relationship between Perceptual Learning Style Preferences and Skill retrieved from http://asian-efl-journal.com/wp-content/uploads/mgm/downloads/01729100.pdf

Naserieh, F., \& Sarab, M. R. A. (2013). Perceptual learning style preferences among Iranian graduate students. System, 41(1), 122-133.

O'Brien, L. (1990). Learning Channel Preference Checklist (LCPC). Rockville, MD: Specific Diagnostic Services.

Oxford, R. L. (1989). Use of language learning strategies: A synthesis of studies with implications for strategy training. System, 17(2), 235-247.

Oxford, R. L. (1993). Style Analysis Survey(SAS). Tuscaloosa, AL: University of Alabama.

Oxford, R. L. (2003, October). Language learning styles and strategies: An overview. Oxford: Gala.

Oxford, R. L., \& Ehrman, M. E. (1989). Psychological type and adult language learning strategies: A pilot study. Journal of Psychological Type, 16, 22-32.

Peacock, M. (2001). Match or mismatch? Learning styles and teaching styles in EFL. International Journal of Applied Linguistics, 11(1), 1-20.

Phoenix, A. (2004). Learning styles and gender. In H. Claire (Ed.), Gender in education 3-19:A fresh approach. The Association of Teachers and Lectures: 33-41.

Prystiananta, N. (2018). Indonesian EFL Students' Learning Styles. Linguistic, English Education and Art (LEEA) Journal, 2(1), 30-42. https://doi.org/https://doi.org/10.31539/leea.v2i1.344

Psaltou-Joycey, A., \& Kantaridou, Z. (2011). Major, minor, and negative learning style preferences of university students. System, 39(1), 103-112 https://doi.org/10.1016/j.system.2011.01.008

Radwan, A. A. (2014). Gender and Learning Style Preferences of EFL Learner. Arab World English Journal, 5(1).

Ramezani, A. E., Dehgahi, M., \& Hashemi, H. (2015). An Exploratory Study of the Language-Learning Style Preferences of Iranian EFL High School Students. Advances in Language and Literary Studies, 6(2), 150-159.

Reid, J. M. (1984). Perceptual Learning Style Preference Questionnaire. Laramie: University of Wyoming, Department of English.

Reid, J. M. (1987). The learning style preferences of ESL students. TESOL Quarterly, 21(1), 87-111. https://doi.org/10.2307/3586356

Reiff, J. C. (1992). Learning styles. Washington, D.C: NEA Professional Library, National Education Association. (Online) https://ia802609.us.archive.org/30/items/ERIC ED340506/ERIC ED340506.pdf

Riazi, A. \& Mansoorian, M. A. (2008). Learning style preferences among Iranian male and female EFL students. The Iranian EFL Journal Quarterly 2: 88-100. (Online) http://hdl.handle.net/1959.14/ 313843

Riazi, M. \& Riasati, M. J. (2007). Language learning style preferences: a case study of Shiraz EFL Institutes. The Asian EFL Journal Quarterly 9 (1):97-125. (Online) http://www.asian-efljournal.com/March 2007 EBook.pdf

Richards, J. C., \& Schmidt, R. W. (2014). Conversational analysis. In Language and communication (pp. 129167). Routledge. 
Riechmann, S. W., \& Grasha, A. F. (1974). A rational approach to developing and assessing the construct validity of a student learning style scales instrument. Journal of Psychology, 87, 213-223.

Sengsouliya, S., Chatouphonexay, A., Phonekeo, S., \& Xaixanith, T. (2019). Probing university-level students' English learning style preferences: A case study of Laotian English majors. The Normal Light Journal, 13(1), http://po.pnuresearchportal.org/ejournal/index.php/normallights/article/view/1241

203-228.

Stebbins, C. 1993. Culture specific perceptual learning style preferences of Post-Secondary students of English as a second language (Master's Thesis, University of Wyoming).

Sun, P. P., \& Teng, L. S. (2017). Profiling perceptual learning styles of Chinese as a second language learners in university settings. Journal of psycholinguistic research, 46(6), 1529-1548.

Tai, F.M.1999. Preferred teaching styles of Taiwanese EFL teachers and preferred learning styles of traditional and nontraditional EFL students (Doctoral dissertation, University of South Dakota). (online) http://ir.lib.ksu.edu.tw/bitstream/987654321/3032/1/\%25E8\%25AB\%2596\%25E6\%2596\%2587.pdf

Widdowson, H. G. (1983). Learning purpose and language use. Oxford etc: Oxford University Press.

Willing, K. (1988). Learning styles in adult migrant education. Sydney: NCELTR.

Wintergerst, A. C., DeCapua, A., \& Itzen, R. C. (2001). The construct validity of one learning styles instrument. System, 29(3), 385-403.doi:10.1016/S0346-251X (01)00027-6

$\mathrm{Xu}, \mathrm{W}$. (2011). Learning styles and their implications in learning and teaching. Theory and Practice in Language Studies, 1(4), 413-416.

Yosraaveevorakul, S., Ekkayokkaya, M., Sangsuwan, S., Lier, L. V., \& Hatfield, R. G. (2017). Learnng Styles of ASEAN Students: A pilot Case Study of Thai Freshmen in English Major at the School of Liberal Arts, Mae Fah Luang University. International Journal of Applied Engineering Research, 14889-14894

Zhang, M., Quan, Y., Huang, L., \& Kuo, Y. L. (2017). The impact of learning styles on academic achievement. International Journal of Intelligent Technologies and Applied Statistics, 10(3), 173185. https:// doi: 10.6148/IJTTAS.2017.1003.04

\section{Author's biodata:}

${ }^{*}$ Dr. Saleem is currently working as an assistant professor at the English Language Unit, Preparatory Year Deanship (PYD), Prince Sattam Bin Abdulaziz University, AlKharj, Saudi Arabia. He holds a PhD in English from India. He has also passed the National Eligibility Test (NET-English) conducted by the University Grants Commision and the State Eligibility Test (APSET-Education) conducted by the Andhra Pradesh Government, India. He has been teaching undergraduates for more than fifteen years in India and Saudi Arabia. His research interests are action research, testing and evaluation, issues in ELT, language and literature, and educational technology.

**Ms. Syeda Mujeeba is an English language instructor at the English Language Unit, Preparatory Year Deanship (PYD), Prince Sattam Bin Abdulaziz University, AlKharj, Saudi Arabia. She holds an M.A. (English), a PGCTE, and a PGDTE from India. She has 10 years of teaching experience in India and Saudi Arabia. Her research interests are issues in ELT and educational technology. 